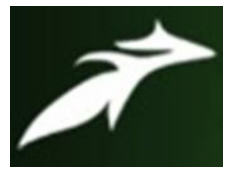

Ashutosh Suryavanshi et al, International Journal of Advances in Agricultural Science and Technology,

Vol.8 Issue.9, September-2021, pg. 1-8

ISSN: 2348-1358

Impact Factor: 6.057

NAAS Rating: 3.77

\title{
IMPACT OF MICRO-FINANCE ON WOMEN EMPOWERMENT IN PRAYAGRAJ DISTRICT, UTTAR PRADESH
}

\author{
Ashutosh Suryavanshi \\ M.Sc. Ag. (Agricultural Extension and Communication), SHUATS (Prayagraj) \\ Prof. (Dr.) Ms. Jahanara \\ Head, Department of Agriculture Extension and Communication, SHUATS (Prayagraj) \\ Department of Agriculture Extension and Communication, SHUATS (Prayagraj) \\ Author's e-mail: ashuvlad96@gmail.com \\ DOI: 10.47856/ijaast.2021.v08i9.001
}

Abstract: Microfinance is a widely accepted tool for poverty alleviation and socio-economic development of its beneficiaries and currently promoted as a key strategy for women empowerment and for reaching the unreached poor. There was lack of knowledge on the impact of microfinance on women empowerment; hence there arises the need for the study. Ex-post facto research design was adopted for the study in Prayagraj district of Uttar Pradesh. Six villages in Holagarh block of Prayagaraj district is selected for the study. From each village, 20 respondents were selected constitutes 120 respondents. The primary data were collected with the help of interview schedule and with appropriate statistical tools the data is processed. The findings of the study are majority of the respondents were middle aged, literate, earns medium level of annual income, low level of mass media exposure, had above 3 acres of land holding, medium level of leadership capacity and medium level of social participation. Further, nearly half of the respondents had medium level of impact on operational aspects and individual aspects of micro-finance on women empowerment and more than two-third of the respondents had medium level of impact of micro-finance on family aspects.

Keywords: Micro-finance, Women empowerment, Impact, Status, SHG.

\section{Introduction}

Microfinance is regarded as a key strategy for women empowerment and helps in reaching the unreached poor. Microfinance is similar to small loan offer to low-income entrepreneurs in underdeveloped nations. Plamondon (2001) reported that microfinance provide financial services such as credit services, money transfers and insurance for poor and 


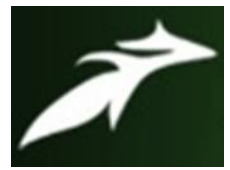

Ashutosh Suryavanshi et al, International Journal of Advances in Agricultural Science and Technology, Vol.8 Issue.9, September-2021, pg. 1-8

ISSN: 2348-1358

Impact Factor: 6.057

NAAS Rating: 3.77

low-income clients. Mohammad Yunus (2006) was awarded the noble peace prize for developing microfinance to create socio-economic development. The most prominent form of micro-financing is microcredit, small loans provide to impoverished households who have been abnegated availableness to credit from conventional banks owing to incompetence to repay it. Micro-credit can provide a range of benefits that poor households highly value including long-term increases in income and consumption (ADB, 2000).

Microfinance fills the capital financial gap which has been incapable to be filled by the rural co-operative and commercial banking organization and its play a substantial role in placing a position amid the endemic bankers and formal banks. The Microfinance Bill, 2007 defines, "Microfinance as the provision of thrift (savings), credit and other financial services and products of very small amounts to the poor for enabling them to raise their income levels and improve living standards." The various elements of micro-finance are micro-credit, micro-saving, micro-insurance, micro-transfer, micro-leasing and micro-housing. Microfinance is an intervention uniquely designed to serve benefits and gratify desideratum of women. Microfinance blessed with the potentiality to aid poor and reduces poverty. It eased the constitution of businesses and self-employment.

Microfinance provides grant-like services to recipients who would otherwise go unserved. Microfinance aims to help women to attain greater level of assets formation and income certainty at family and social level. Women targeted Microfinance program is a positive measure to bridge the gender gap among men and women. It helps women to deal household financial affairs more considerably, to enhance incomes and to improve livelihood. Numerous microfinance services uplifting the economic, social and financial condition of women. Morduch and Haley (2002) reported that access to microfinance will help the poor to gain access on education. Manjoor and Manders (2009) revealed that women are about 70\% of world's poorest 


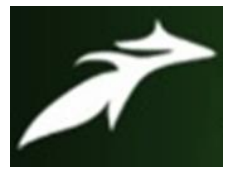

Ashutosh Suryavanshi et al, International Journal of Advances in Agricultural Science and Technology, Vol.8 Issue.9, September-2021, pg. 1-8

ISSN: 2348-1358

Impact Factor: 6.057

NAAS Rating: 3.77

people owing to gender inequality. India is developing country, where women are dominants controlled by male in domestic matters which exhibits a very weak position in society.

Arindam (2015) stated that microfinance outreach to the women is high, the status of women empowerment is also correspondingly high. In a way, it can be said that an all-inclusive microfinance system with a wider outreach is the key to strengthen the financial inclusion process and thus bringing true women empowerment in the country. Dixit (2016) studied the impact of microfinance and reported that women got their confidence increased. Yasmeen et.al., (2017) reported that microfinance brought knowledge and social empowerment than economic empowerment. Gnawali (2018) reported that microfinance institutions plays a positive role on women who invest in them by increasing their well-being, access to and control their resources., eradicating illiteracy among women, taking part in economic decisions and finally microfinance institution have boosted women's self-esteem.

Rajendran and Raya (2010) reported that microfinance brought psychological and social empowerment than economic empowerment. Impact of micro finance was appreciable in bringing confidence, courage, skill development and empowerment but there was no positive impact in sustainable rural development especially reduction of poverty, creation of employment opportunities and creation of assets in rural areas. There was also appreciable development in planning, coordination, decision making and financial skills among the leader respondents. But the effect of micro finance on communication, organizing, competency and technical, marketing skills and entrepreneurial skills was moderate only. There was a definite improvement of managerial skills, psychological well being and social empowerment among rural women as a result of participating in micro finance through SHG programme.

Lyngdoh and Patil (2013) highlights that microfinance has a positive impact on income, expenditure and savings. Gangadhar and Malyadri (2015) reported that microfinance is a powerful tool in enhancing women empowerment for its all indicators like household economic 


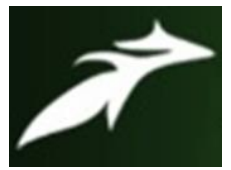

Ashutosh Suryavanshi et al, International Journal of Advances in Agricultural Science and Technology, Vol.8 Issue.9, September-2021, pg. 1-8

ISSN: 2348-1358

Impact Factor: 6.057

NAAS Rating: 3.77

decision making, legal awareness, mobility, economic security and family decision making. Bhatt (2016) revealed that the loan resulted in the increase in income of the women members thus mounting their self-worth and confidence.

\section{Research Methodology}

Ex-post facto research design was adopted for the study since it was conducted in an already existing phenomenon. Prayagraj district of Uttar Pradesh is selected since it possesses many micro financing agencies and the researcher was well-conversant with the study area. Out of 23 blocks, Holagarh block of Soraon tehsil has been selected by purposive sampling because micro finance availability is comparatively more. In Holagarh block of Prayagraj district, out of 92 villages, six villages were selected purposively based on the maximum area covered under micro finance scheme. The selected villages were, Kasturipur, Paschim Nara, Poorab Nara, Hansrajpur, Barai Harakh and Girdharpurgondwa. From each village, 20 respondents were selected. Thus, from six villages 120 respondents were selected for the study. The primary data were collected with the help of interview schedule and the responses were recorded, classified and tabulated and appropriate statistical tools were employed.

\section{Results and Discussion}

The socio-economic profile of the respondents was studied under various characteristics and the results were presented under table.1.

Table.1. Socio-economic profile of the respondents $(n=120)$

\begin{tabular}{|c|c|l|c|c|}
\hline S. No. & Characteristics & \multicolumn{1}{|c|}{ Category } & Frequency & Percentage \\
\hline 1 & Age (in years) & Young (<35) & 34 & 28.34 \\
\cline { 3 - 5 } & & Middle(36-55) & 64 & 53.33 \\
\cline { 3 - 5 } & & Old (>55) & 22 & 18.33 \\
\hline 2 & Education & Illiterate & 34 & 28.34 \\
\cline { 3 - 5 } & & Primary & 12 & 10.00 \\
\hline
\end{tabular}




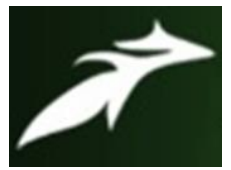

Ashutosh Suryavanshi et al, International Journal of Advances in Agricultural Science and Technology, Vol.8 Issue.9, September-2021, pg. 1-8

ISSN: $2348-1358$

Impact Factor: 6.057

NAAS Rating: $\mathbf{3 . 7 7}$

\begin{tabular}{|c|c|c|c|c|}
\hline & & Junior high school & 14 & 11.67 \\
\hline & & High school & 17 & 14.17 \\
\hline & & Intermediate & 36 & 30.00 \\
\hline & & Graduate and above & 7 & 5.83 \\
\hline \multirow[t]{2}{*}{3} & \multirow[t]{2}{*}{ Occupation } & Agriculture & 69 & 57.5 \\
\hline & & Agriculture + Subsidiary & 51 & 42.5 \\
\hline \multirow[t]{2}{*}{4} & \multirow[t]{2}{*}{ Family type } & Nuclear family & 98 & 81.67 \\
\hline & & Joint family & 22 & 18.33 \\
\hline \multirow[t]{2}{*}{5} & \multirow[t]{2}{*}{ Family size } & Upto 5 members & 96 & 80.00 \\
\hline & & More than 5 members & 24 & 20.00 \\
\hline \multirow[t]{4}{*}{6} & \multirow[t]{4}{*}{ Land holding } & Below 1 acre & 15 & 12.50 \\
\hline & & $1-2$ acre & 15 & 12.50 \\
\hline & & 2-3 acres & 30 & 25.00 \\
\hline & & Above 3 acres & 60 & 50.00 \\
\hline \multirow[t]{3}{*}{7} & \multirow[t]{3}{*}{ Annual income } & Low (upto 50,000) & 51 & 42.50 \\
\hline & & Medium $(50,000-1$ lakh $)$ & 57 & 47.50 \\
\hline & & High ( above 1 lakh) & 12 & 10.00 \\
\hline \multirow[t]{3}{*}{8} & \multirow[t]{3}{*}{ Mass media exposure } & Low & 63 & 52.50 \\
\hline & & Medium & 48 & 40.00 \\
\hline & & High & 9 & 7.50 \\
\hline \multirow[t]{3}{*}{9} & \multirow[t]{3}{*}{ Leadership capacity } & Low & 30 & 25.00 \\
\hline & & Medium & 65 & 55.00 \\
\hline & & High & 24 & 20.00 \\
\hline \multirow[t]{3}{*}{10} & \multirow[t]{3}{*}{ Social participation } & Low & 12 & 10.00 \\
\hline & & Medium & 63 & 52.50 \\
\hline & & High & 39 & 32.50 \\
\hline
\end{tabular}




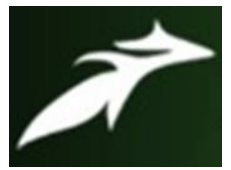

Ashutosh Suryavanshi et al, International Journal of Advances in Agricultural Science and Technology, Vol.8 Issue.9, September-2021, pg. 1-8

ISSN: 2348-1358 Impact Factor: 6.057 NAAS Rating: $\mathbf{3 . 7 7}$

From table.1, it can be interpreted that more than half of the respondents were middle aged (53.33\%), followed by young aged (28.34\%) and old aged (18.33\%). Most of the respondents were literate $(71.67 \%)$, of which majority were intermediate $(30 \%)$, followed by high school (14.17\%), junior high school (11.67\%), primary (10\%) and graduate \& above (5.83\%). Only 28.34 per cent of respondents were illiterate. More than half of the respondents had agriculture as their main occupation (57.5\%) and agriculture + subsidiary occupation as their subsidiary occupation (42.5\%). More than three-fourth of the respondents had nuclear family $(81.67 \%)$ followed by 18.33 per cent had joint family. More than three-fourth of the respondents had up to 5 members (80\%) and only 20 per cent of respondents had more than 5 members.

Nearly half of the respondents earns medium level of annual income (47.50\%), followed by low (42.50\%) and high (10\%) level of annual income. More than half of the respondents had low level of mass media exposure (52.50\%), followed medium level of mass media exposure (40\%) and high level of mass media exposure (7.50\%). Half of the respondents had above 3 acres of land holding (50\%), followed by 25 per cent of the respondents had 2-3 acres of land holding and an equal proportion of respondents had below 1 acre (12.50\%) and 1-2 acres of land holding (12.50\%). Majority of the respondents had medium level of leadership capacity (55\%), followed by low (25\%) and high (20\%) level of leadership capacity. More than half of the respondents $(52.50 \%)$ had medium level of social participation, followed by high $(32.50 \%)$ and low $(10 \%)$ level of social participation.

Table.2. Impact of microfinance on women empowerment

$(n=120)$

\begin{tabular}{|c|c|c|c|c|}
\hline S. No. & Impact & Category & Frequency & Percentage \\
\hline \multirow{2}{*}{1} & Impact on operational & Low & 21 & 17.50 \\
\cline { 3 - 5 } & aspects of microfinance & Medium & 59 & 49.17 \\
\cline { 3 - 5 } & on women empowerment & High & 38 & 31.67 \\
\hline
\end{tabular}




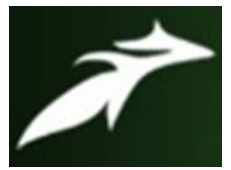

Ashutosh Suryavanshi et al, International Journal of Advances in Agricultural Science and Technology, Vol.8 Issue.9, September-2021, pg. 1-8

ISSN: 2348-1358

Impact Factor: 6.057

NAAS Rating: 3.77

\begin{tabular}{|c|c|c|c|c|}
\hline 2 & Impact on individual & Low & 15 & 12.50 \\
\cline { 3 - 5 } & \multirow{2}{*}{$\begin{array}{c}\text { aspects of microfinance } \\
\text { on women empowerment }\end{array}$} & Medium & 48 & 40.00 \\
\cline { 3 - 5 } & & High & 57 & 47.50 \\
\hline 3 & Impact on family & Low & 24 & 20.00 \\
\cline { 3 - 5 } & $\begin{array}{c}\text { aspects of microfinance } \\
\text { on women empowerment }\end{array}$ & Medium & 78 & 65.00 \\
\cline { 3 - 5 } & & High & 18 & 15.00 \\
\hline
\end{tabular}

From table.2, it can be interpreted that nearly half of the respondents had medium level of impact on operational aspects of micro-finance on women empowerment (49.17\%), followed by high (31.67\%) and low (17.50\%) level of impact. Nearly half of the respondents had high level of impact on individual aspects of micro-finance on women empowerment (47.50\%), followed by medium (40\%) and low (12.50\%) level of impact. More than two-third of the respondents had medium level of impact of micro-finance on family aspects (65\%), followed by low (20\%) and high (15\%) level of impact on micro-finance on family aspects on women empowerment.

\section{Conclusion}

Thus it was concluded that from the above study that microfinance is playing a vital role in the social, psychological as well as economic empowerment of women in India. Microfinance loan availement and its productive utilization found to be having a profound role and impact on women empowerment. The empirical findings of the study suggests that microfinance has a profound influence on the economic status, decision making power, knowledge and self worthiness of women participants of self-help group linkage program in Ghaziabad. Microfinance is accepted as a key mantra for attaining and maintaining the sustained and longterm economic growth in all over the world. Reaching poor people on massive scale with popular products on a continuous basis involves rethinking the basic assumptions and making the 


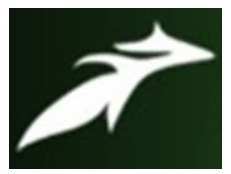

Ashutosh Suryavanshi et al, International Journal of Advances in Agricultural Science and Technology, Vol.8 Issue.9, September-2021, pg. 1-8

ISSN: 2348-1358

Impact Factor: 6.057

NAAS Rating: 3.77

changes. Today microfinance is striving to match the convenience and flexibility of informal sector while adding flexibility and continuity.

\section{REFERENCES}

[1]. Achyut Gnawali "Impact of Microfinance Institutions in Women Economic Empowerment: With reference to Butwal Sub-Municipality". International Journal of Research in Humanities and Social Studies, 5(5), pp.10-17.

[2]. ADB 2000 Finance for the poor: Micro Finance Development Strategy. Washington DC, USA. Asian Development Bank.

[3]. Arindam Laha \& Pravat Kumar Kuri (2014) Measuring the Impact of Microfinance on Women Empowerment: A Cross Country Analysis with Special Reference to India, International Journal of Public Administration, 37:7,397-408, DOI: 10.1080/01900692.2013.858354

[4]. Bhatt G D.2016. Empowerment and status of Rural women. MD Publications Pvt., Ltd., New Delhi.

[5]. Lyngdoh BF, Pati AP. Impact of Microfinance on Women Empowerment in the Matrilineal Tribal Society of India: An Analysis Using Propensity Score Matching and Difference-in-Difference. International Journal of Rural Management. 2013;9(1):45-69. doi: $10.1177 / 0973005213479207$

[6]. Manjoor, H. and Manders, J. (2009). "Women Empowerment: Comparing concepts \& Assessment Implications for microfinance.” Commissioned by Oiko credit.

[7]. Morduch, J. and Haley, B. (2002), Analysis of the Effects of Microfinance on Poverty Reduction. NYU Wagner Working Paper Series, (1014), 1- 170.

[8]. Plamondon, J 2001, Executive Summary of Micro-Finance in Cambodia, Phnom Penh, Cambodia, p. 4.

[9]. Rajendran. K and Raya. R P (2010). Impact of micro finance: An empirical study on the attitude of SHG leaders in Vellore districts of Tamil Nadu, Global Journal of Finance and Management, Vol-2 No-1(2010), pp. 59-68.

[10].Sujatha Gangadhar CH, Malyadri P (2015) Impact of Microfinance on Women Empowerment: An Empirical Evidence from Andhra Pradesh. J Entrepren Organiz Manag 4: 141. doi:10.4172/2169-026X.1000141

[11].Yasmeen, S., Abdul, J. M., Najaf, D. 2017. Impact of microfinance on women empowerment through poverty alleviation: An assessment of socio-economic conditions in Chennai city of Tamil Nadu. Asian Journal of Poverty Studies. 3(2).

[12]. Yunus, M. (2006). Creating a world without poverty: Social business and the future of capitalism. New York, NY: Public Affairs. 